\title{
Forestry under Climate Change. Is Time a Tool for Sustainable Forest Management?
}

\author{
Fabrizio D'Aprile1, Nigel Tapper'1, Marco Marchetti2 \\ ${ }^{1}$ School of Earth, Atmosphere \& Environment, Monash University, Melbourne, Australia \\ ${ }^{2}$ Department of Bioscience and Territory, University of Molise, Isernia, Italy \\ Email: fabrizio.daprile@monash.edu, nigel.tapper@monash.edu, marchettimarco@unimol.it
}

Received 22 February 2015; accepted 15 March 2015; published 20 March 2015

Copyright (C) 2015 by authors and Scientific Research Publishing Inc.

This work is licensed under the Creative Commons Attribution International License (CC BY). http://creativecommons.org/licenses/by/4.0/

(c) (i) Open Access

\begin{abstract}
Changing climate conditions are known to influence forest tree growth response and the $\mathrm{CO}_{2} \mathrm{Cycle}_{\text {. }}$ Dendroclimatological research has shown that the climate signal, species composition, and growth trends have changed in different types of forest ecosystems during the last century. Under current and demonstrated changes in climate variability at the geographic, regional, and local levels tree growth shows also variability and trends that can be non-stationary during time even at relatively short distance between sites. In forest planning and management, yield tables, site quality indices, age class, rate of growth, and spatial distribution are some of the most used tools and parameters. However, these methods do not involve climate variability during time although climate is the main driver in trends of forest and tree growth. Previous research warns about the risk that forest management under changing climatic conditions could amplify their negative effects. For example, changing climate conditions may impact on temperature and/or precipitation thresholds critical to forest tree growth. Forest biomass, resilience, and $\mathrm{CO}_{2}$ storage may be damaged unless forest planning and management implement the relationships between climate variability and trends of tree growth. A positive aspect is that, periods of favorable climate conditions may allow harvesting higher amount of wood mass and storing more $\mathrm{CO}_{2}$ than traditional planning methods. And, the average length of both favorable and adverse periods appears to occur within the validity period of a forest management plan. Here, we show a conceptual development to implement climate variability in forest management in the view of continuing the research.
\end{abstract}

\section{Keywords}

Climate Change, Forestry, Sustainability, Time Factor, Management

\section{Introduction}

Changes of climate conditions influence energy fluxes, cycles of nutrients and materials, primary productivity, 
biodiversity, ecological functions and carbon equilibria of forest ecosystems; time factors influence physical, biological, ecological, and climatic processes and functions. For example, seasonality, cycles, periodicity, and trends in climate variables; tree growth, forest growth, and forest metabolic activities (i.e., photosynthesis and respiration) are commonly known to be time-related.

A real risk for sustainable forest management (SFM) under changing climatic conditions is that negative effects may be amplified. In fact, variability in trends of climate variables can highly influence forest growth by either increasing or reducing it in different periods (Bertini et al., 2011; Mérian et al., 2013). Changing climate conditions may impact on temperature and/or precipitation thresholds critical to forest tree growth. For example, critical thresholds of temperature and/or rainfall for tree growth and stress may be exceeded, and impacts on growth response, resilience, and $\mathrm{CO}_{2}$ balance that are not completely known, may occur. However, the distribution, rate of growth, and volume of wood in traditional forest planning and management is frequently based on yield tables or similar tools, age classes, site quality indices, and spatial distribution criteria, which do not implement the effects of climate changing conditions on forest growth variability and trends over time. Thus, this kind of approach cannot identify and estimate when, how, and where the forest and its parcels go through periods of increasing (or decreasing) growth, which is driven mainly by climate variability. Moreover, temporal changes in silvicultural and harvesting operations may lead to an increase of carbon emissions.

Normally, forest management emphasizes growth rates and biomass productivity as expressions of species and site (Sedmák \& Scheer, 2015). Until recently, the influence of climate variability on growth dynamics has not been included in forest planning and management. Here we show a conceptual development aiming to highlight a relevant physical factor in forest planning and management; that is time. Although time is a typical tool in forest planning, it has traditionally been used just as a technical parameter to base forest yield and/or age classes and schedule forest operations.

Today, its relevance as a physical factor that regulates forest growth, dynamics, and functionality in relation to the effects of climate variables needs to be implemented in SFM for the development of mitigation and adaption strategies under the effects of changing climate conditions, including $\mathrm{CO}_{2}$ storage.

Under this scenario and the consequent risks, SFM and operations could be planned and/or scheduled in periods when climate variables that influence tree growth responses are within the relative thresholds. By using this approach, silvicultural operations and harvesting are likely going to be related mainly to climate variability and forest growth responses.

\section{Time as a Key Factor in Climate Change and Tree Growth}

Biodiversity and climate are components of the complex regulatory mechanism that balances the energy exchange between the planet and the universe. Biodiversity can also be seen as the results of complex interactions between the molecular (i.e., DNA) level and the atmospheric level during natural history; in other words, the evolution and adjustment of the energetic balance between Earth and Space. In recent decades, the concentration of $\mathrm{CO}_{2}$ in the atmosphere has reached high levels in short time. Among its effects on climate and vegetation, there are global warming (greenhouse effect) and modification of the $\mathrm{CO}_{2}$ cycle. Today, research shows that using and managing forests needs to implement the mitigation of impacts of climate change and the development of adaption strategies in forest management (Falk \& Mellert, 2011; Linares \& Camarero, 2012; Lafortezza et al., 2013), including $\mathrm{CO}_{2}$ storage.

\subsection{The Context}

Changing climate conditions frequently interact with forest growth at the local level within regional scenarios; the influence of variability and intensity of climate alterations at the forest level may be even stronger than regional trends (master series) (D’Aprile et al., 2009). At the local level, similarity in trends of climate variables can differ markedly and irregularly over time. Changing climate conditions can also modify both the extent of the growing season and the months that influence the occurrence of tree growth response (Pretzsch et al., 2014). This information is relevant from a scientific point of view; the complexity of interactions between climate variability and forest growth and dynamics requires an effort to make it applicable to the reality of SFM. In forest planning and management, however, dynamics, growth, and modifications of forest structures can be partially identified and modeled through time. 


\subsection{Time in Forest Monitoring and Planning}

In forest ecology, it may be noted that:

- Cause-effect relationships are objectives that mainly concern the analysis of fluxes of energy and matter(s); these relationships take place through biodiversity and ecological groups of species;

- In forest ecosystems many variables interact through the complex of their dynamics and properties. Therefore, indicators and models are needed to interpret the complexity of cause-effect relationships and how they work. In this scenario, changing climate conditions add to complicate the management of forests and land and their effects are not completely understood yet;

- Understanding the cause-effect relationships intrinsically involve the variable time. In fact, time is a powerful and necessary driver of physical, biological, ecological, and climatic processes and functions; and many others.

\subsection{Trends in Climate Variability and Forest Growth at the Site Level}

\subsubsection{Non-Stationary Similarity in Climate Variability}

Our research (D’Aprile et al., 2010) has shown that in the Apennine Alps (Middle Italy) during the $20^{\text {th }}$ century, the trends in monthly mean temperature are non-stationary, their similarity vary highly and irregularly among sites and can be even opposite in sign in some periods; similarity in trends among sites varies also with season. This phenomenon can occur even between sites at short distance. Similar results have been found with respect to monthly rainfall (D’Aprile et al., 2011).

\subsubsection{Non-Stationary Trends in Tree Growth}

We investigated also the similarity in tree-ring growth (Abies alba Mill.) in the meteorological station sites (i.e., Abetone (Pistoia), Camaldoli (Arezzo), La Verna (Arezzo), Vallombrosa (Florence)) (Table 1). Results have shown high and irregular non-stationarity in similarity of tree ring chronologies among sites and, at lower extent, along elevation gradients within forest sites (Figure 1).

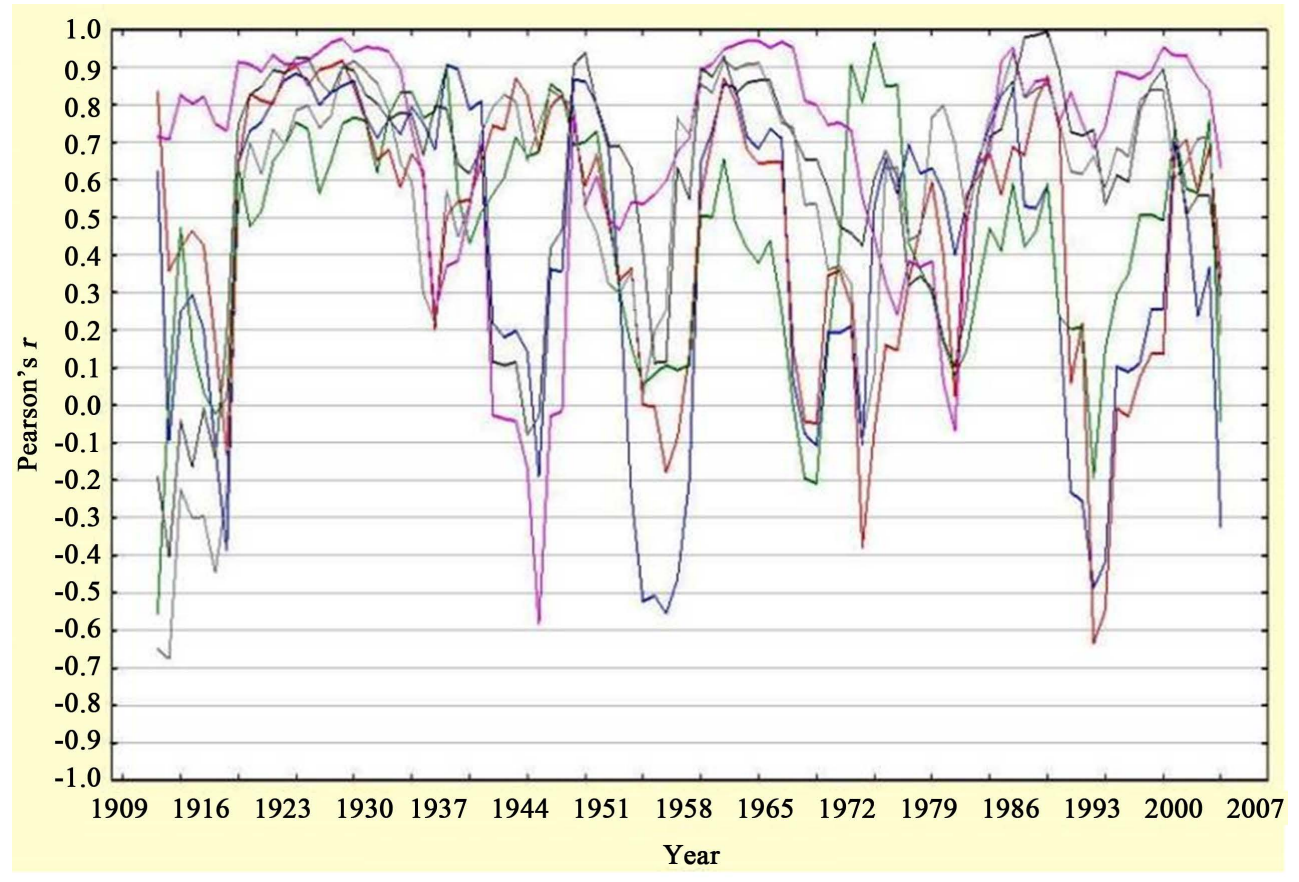

Figure 1. Non-stationary correlation of 7-year moving averages between "Residual tree-ring chronologies, RTRs among the upper study stands of silver fir in the Apennine Alps during the period 1909-2007. Abetone-Camaldoli is blue, Abetone-La Verna is red, Abetone-Vallombrosa is green, Camaldoli-La Verna is magenta, Camaldoli-Vallombrosa is dark grey, and La Verna-Vallombrosa is light grey. Source: D’Aprile et al., 2012. 
Table 1. Elevation (m.a.s.l.), available period (year) of data available, and distance (km) between the four meteorological stations. The sites are listed by decreasing elevation. Abetone is ABE, Camaldoli is CAM, La Verna is LAV, and Vallombrosa is VAL.

\begin{tabular}{cccccc}
\hline & Elevation & Period & \multicolumn{3}{c}{ Distance } \\
\hline ABE & 1340 & $1931-2000$ & 112.3 & 100.1 & 84.6 \\
CAM & 1120 & $1924-2006$ & - & 13.2 & 30.4 \\
LAV & 1111 & $1885-1996$ & - & - & 22.3 \\
VAL & 955 & $1872-2006$ & - & - & - \\
\hline
\end{tabular}

\subsubsection{Climate/Tree Growth Relationships during the 20 $0^{\text {th }}$ Century}

The evidence of high and irregular non-stationary similarity in trends of both climate variables and tree-ring chronologies in the same sites suggested verifying if there is any association between climate variability and tree growth trends. Thus, we investigated the climate/tree-ring correlations more to determine if there have been temporal fluctuations in the strength of the associations. Running-means correlation analysis showed that the tree-ring/climate relationships vary markedly during the $20^{\text {th }}$ century. In particular, we found that correlations vary highly in strength and also in sign (Figure 2) and the influence of months on tree growth changes over decades (Figure 3) (D’Aprile et al., 2012). In other words, the association between climate variables and tree growth varies among sites and throughout months. These results provide evidence that tree-ring/climate relationships in the Tuscan Apennine Alps (Middle Italy) have been non-stationary during the 20th century.

\section{Questions for Research Development}

The scenario and results shown above raise these questions:

1) Are traditional or rigidly scheduled forest management operations damaging or worsening the resilience of forest ecosystems and their ability to store $\mathrm{CO}_{2}$ under changing climate conditions?

2) Can time be used to adapt flexible forest management operations to variability in climate factors proved to influence forest/tree growth?

3) Can timing in forest management be used to maintain both sustainable forest productivity and high rate of $\mathrm{CO}_{2}$ storage?

\section{Forest Utilization under Changing Climate Conditions}

The impacts of climate change on forest and silvicultural management may be summarized by four main situations. Harvesting may occur in periods when (Figure 4):

- During troughs of the rate of growth. The minimum biomass necessary to preserve the resilience of the forest is damaged. Damage can be temporary (decades) or permanent; $\mathrm{CO}_{2}$ storage capacity is deficient ore reduced-which may be read as an indirect emission of $\mathrm{CO}_{2}$ as the balance is negative (red color);

- The rate of growth decreases. Future productivity is damaged; the minimum biomass capital may be altered, and $\mathrm{CO}_{2}$ storage is negatively affected (light brown color, descending curve);

- The rate of growth increases. The planned wood mass can be used without compromising the resilience and recovery of the forest; $\mathrm{CO}_{2}$ storage remains increasing (light brown color, ascending curve);

- During peak periods of growth. The wood mass harvested can be even higher than planned, and the rate of $\mathrm{CO}_{2}$ storage can be above the average (light blue color).

Under changing climate conditions, a real risk is that interventions (thinning, cutting, harvesting) occur in a period unfavorable or adverse to forest species growth, which is not detected or shown by traditional forest management planning. In this case, the mass of wood to harvest predicted by the forest management plan may be higher than the real productivity of the forest and the productive or stable biomass itself is reduced. A side effect is that $\mathrm{CO}_{2}$ storage diminishes as the rate of growth decreases. Under these circumstances, the process leads to indirect emission of $\mathrm{CO}_{2}$ by consuming more wood mass than it is produced (negative balance) and lowering the potential $\mathrm{CO}_{2}$ storage as the forest biomass is smaller and the growth is decreasing. Vice versa, the 


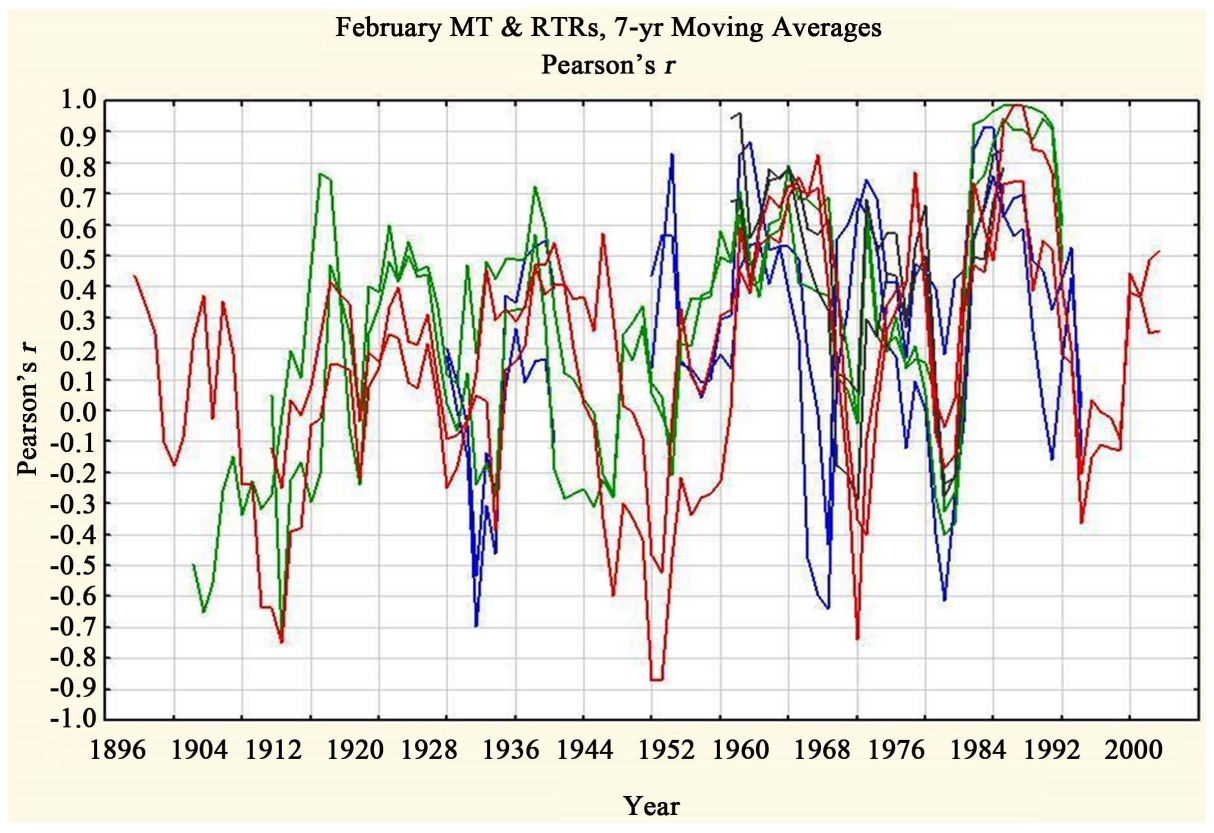

Figure 2. Non-stationary association of "Monthly mean temperature, MMT" with "Residual tree-ring chronologies, RTRs" in February of the growth year. The correlation of MMT with RTRs varies highly with month and site during the $20^{\text {th }}$ century. In the figure, blue is Abetone, Pistoia, green is Camaldoli, Arezzo, dark grey is La Verna, Arezzo, and red is Vallombrosa, Florence. Different trends of the same color show upper and lower study stands. Source: D’Aprile et al., 2012.

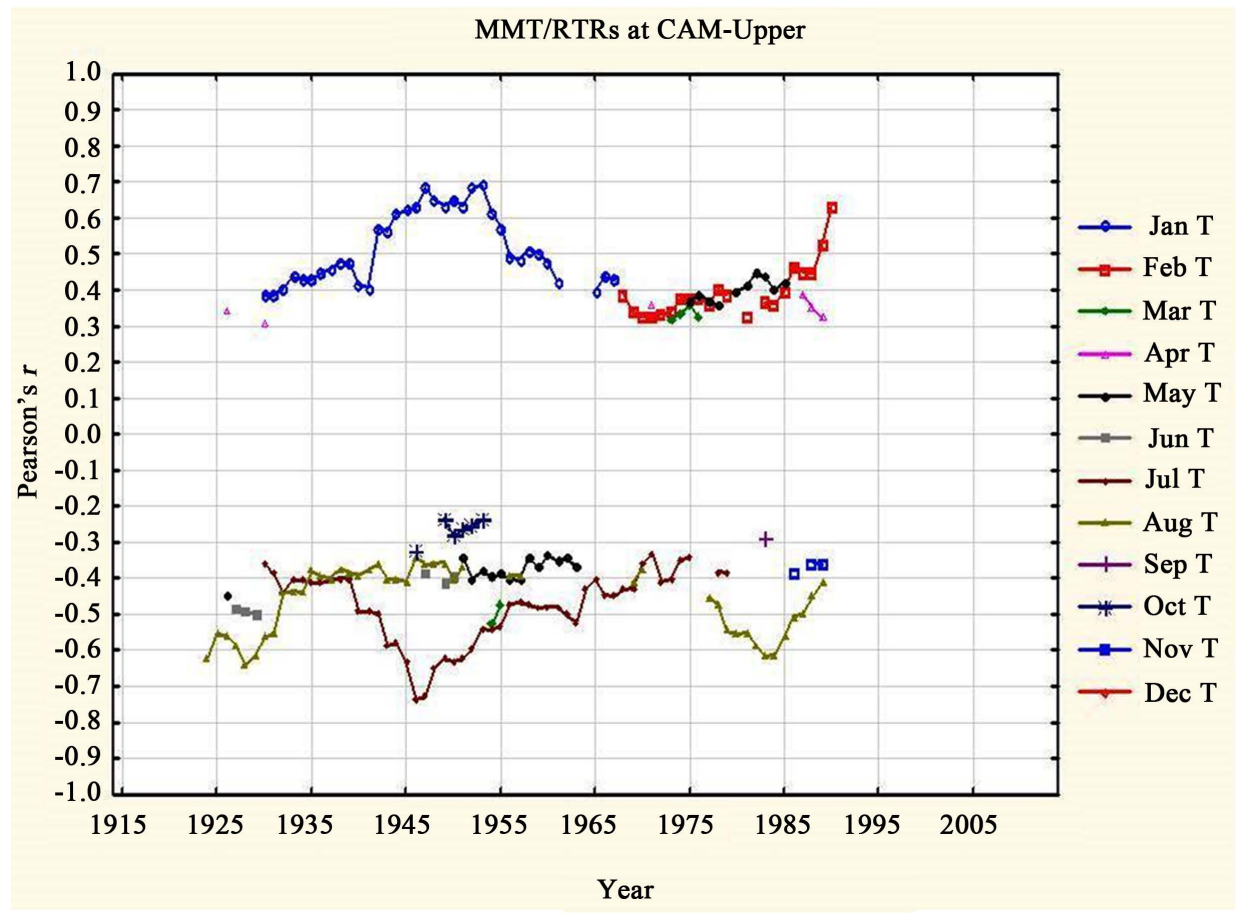

Figure 3. Statistically significant levels of correlation between "Monthly mean temperature, MMT" and "Residual tree-ring chronologies, RTRs" at the study stands at "Camaldoli upper site, CAM-Upper" in the Tuscan Apennine Alps. Associations of MMT with RTRs change during the $20^{\text {th }}$ century and their levels of correlation are highly non-stationary. Source: D’Aprile et al., 2012. 


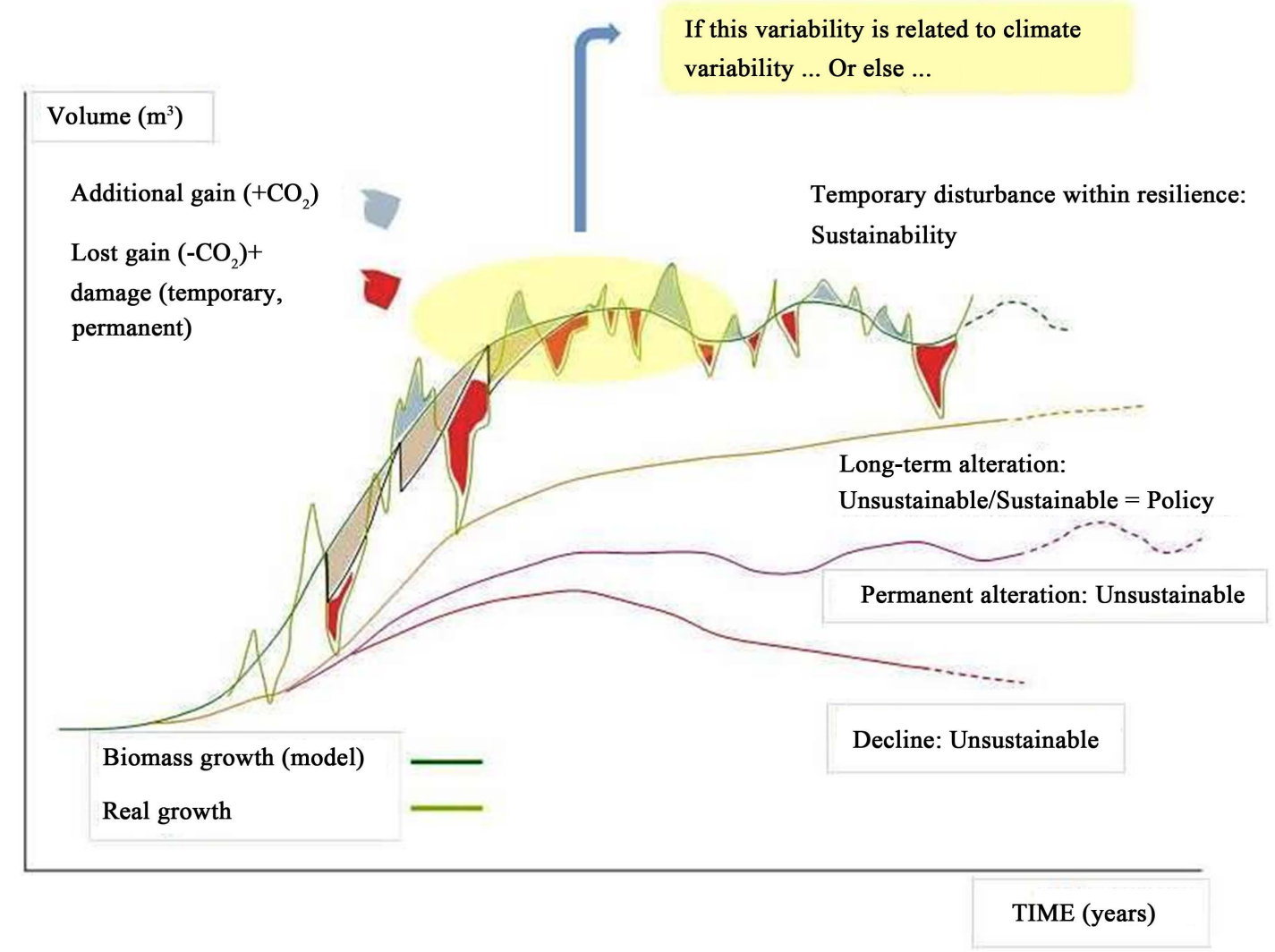

Figure 4. Timing and possible effects of silvicultural interventions and harvesting without implementing climate variability and trends.

extraction of wood during a period of favorable climate conditions that start a positive trend in forest growth may allow harvesting higher wood mass than otherwise planned by using yield tables or growth indices; the productive capacity or stable biomass of the forest is intact. Moreover, $\mathrm{CO}_{2}$ storage may be higher as the rate of growth increases and the wood mass after harvesting is higher.

\section{Conclusion}

The objective of the method is to identify the periods in climate variables—which seem to be 6 - 7 years long in the Tuscan Apennine Alps (Middle Italy) — when forest species growth is positive (or negative) to plan management and interventions by following the variability in growth trends caused by climate variability during time (Figure 5). This can be achieved by identifying the upper and lower thresholds of climate variables (i.e., temperature and/or rainfall) for forest species growth. Once the range of temperature and/or rainfall within which tree growth responds is identified, it is relatively easy to identify the periods when growth increases or decreases in correspondence with historical series of climate variables. It can be noted that growth response to thresholds of temperature and rainfall is genetically determined and therefore it is practically constant through centuries (and longer). So, they can be investigated and identified once for many decades in the future.

Thus, forest planning and management, which dispose for interventions for a few (5 - 10) years normally, can work by identifying periods for operations and interventions on the basis of temperature and/or rainfall within the range of threshold values that produce positive growth trends. As these trends cover periods of a few years (5 - 15), short-term climate variable analysis can show the trend over the period.

To apply these criteria and method, further research is necessary to identify which climate variables and the relative thresholds drive growth response by species, forest type, and ecoregion, and test the forest response in terms of variability in rate of growth, productivity, biodiversity, and $\mathrm{CO}_{2}$ balance in relation to climate trends at the site level. 


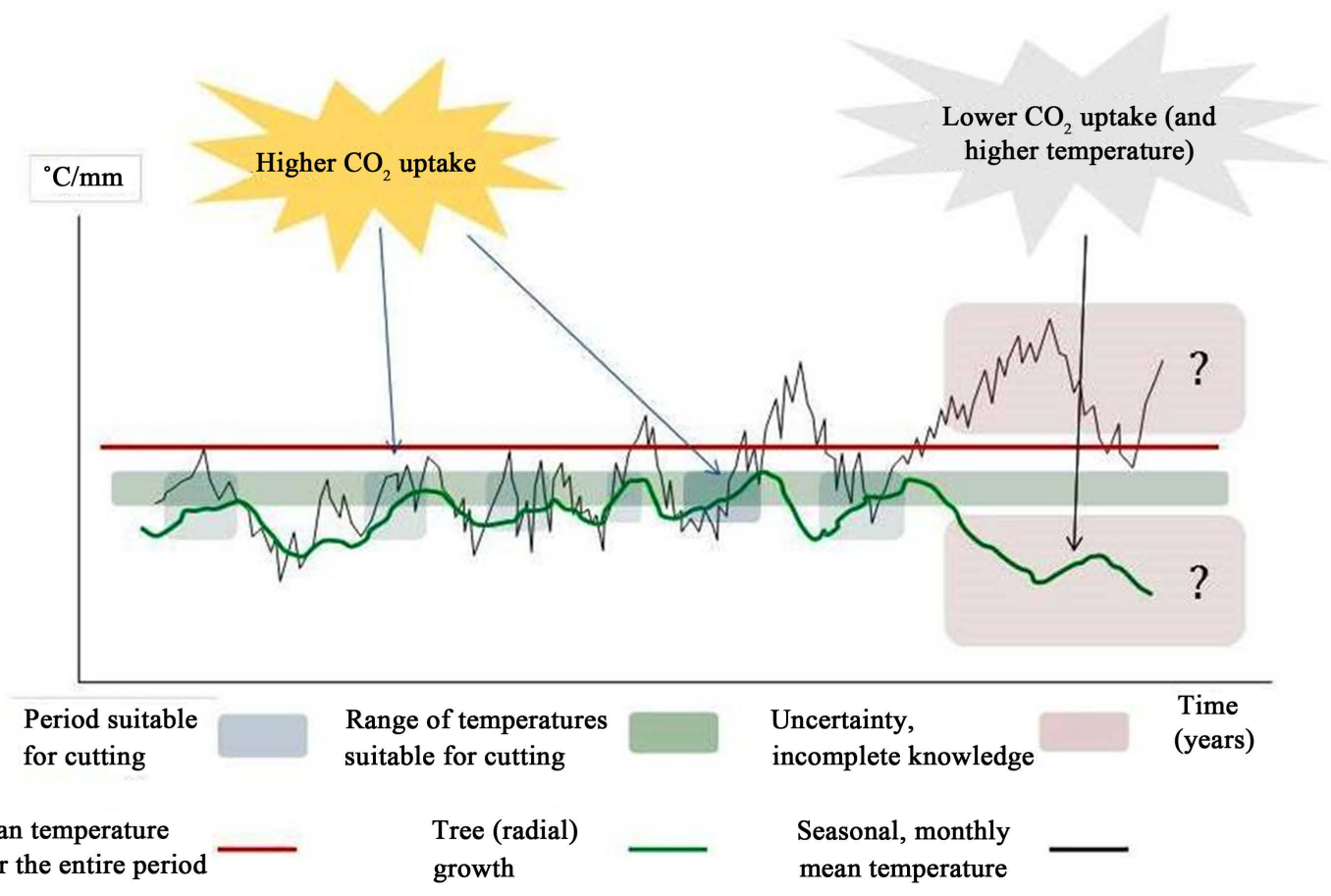

Figure 5. Periods of growth increase crossed with a suitable range of temperature and/or rainfall thresholds for tree growth can identify time and length in forest planning, management, and interventions.

\section{Acknowledgements}

This research was supported by Monash University, School of Earth, Atmosphere \& Environment, Melbourne, Australia. The authors would like to thank Dr. Paul McShane from the Monash Sustainability Institute for his assistance in theory development.

\section{References}

Bertini, G., Amoriello, T., Fabbio, G., \& Piovosi, M. (2011). Forest Growth and Climate Change: Evidences from the ICPForests Intensive Monitoring in Italy. iForest, 4, 262-267. http://www.sisef.it/iforest/contents/?id=ifor0596-004 http://dx.doi.org/10.3832/ifor0596-004

D’Aprile, F., Tapper, N., Baker, P., \& Bartolozzi, L. (2009). Radial Growth Response of Silver Fir (Abies alba Mill.) in Tuscany and Climate Influence: First Results. In Proceedings of the Third National Congress of Silviculture for the Improvement and Conservation of the Italian Forests (pp. 541-546). Firenze: Italian Academy of Forest Sciences. (In Italian) http://dx.doi.org/10.4129/CNS2008.075

D’Aprile, F., Tapper, N., Baker, P., \& Bartolozzi, L. (2009). Climate Influence and Radial Growth of Silver Fir (Abies alba Mill.) in Tuscany: First Results. Geophysical Research Abstracts, Vol. 11, EGU2009-3826-1, EGU General Assembly, Vienna, 2009. http://meetingorganizer.copernicus.org/EGU2009/EGU2009-3826-1.pdf

D’Aprile, F., Tapper, N., Baker, P., \& Bartolozzi, L. (2010). Variability in Trends of Monthly Mean Temperature among Sites in the Tuscan Apennine Alps. Geophysical Research Abstracts, EGU2010-5681-3, EGU General Assembly, Vienna, 2010. http://meetingorganizer.copernicus.org/EGU2010/EGU2010-5681-3.pdf

D’Aprile, F., Tapper, N., Bartolozzi, L., \& Bottacci, A. (2011). Non-Stationary Similarity in Trends of Monthly Rainfall in the Tuscan Apennine Alps. Geophysical Research Abstracts, Vol. 13, EGU2011-1170-1, EGU General Assembly, Vienna, 2011. http://presentations.copernicus.org/EGU2011-1170 presentation.pdf

D’Aprile, F., Tapper N., Baker, P. Bartolozzi, L., \& Bottacci, A. (2012). Changes in the Relationships between Climate and Silver Fir (Abies alba Mill.) Growth during the 20th Century in the Tuscan Apennine Alps (Middle Italy). Geophysical Research Abstracts, Vol. 14, EGU2012-425-1, EGU General Assembly, Vienna, 2012. http://presentations.copernicus.org/EGU2012-425_presentation.pdf

Falk, W., \& Mellert, H. M. (2011). Species Distribution Models as a Tool for Forest Management Planning under Climate Change: Risk Evaluation of Abies alba in Bavaria. Journal of Vegetation Science, 22, 621-634. 
Lafortezza, R., Sanesi, G., \& Chen, J. (2013). Large-Scale Effects of Forest Management in Mediterranean Landscapes of Europe. iForest, 6, 342-346. http://www.sisef.it/iforest/contents/?id=ifor0960-006

Linares, J. C., \& Camarero, J. J. (2012). Growth Patterns and Sensitivity to Climate to Predict Silver Fir Decline in the Spanish Pyrenees. European Journal of Forest Research, 131, 1001-1012. http://dx.doi.org/10.1007/s10342-011-0572-7

Mérian, P., Bert, D., \& Lebourgeois, F. (2013). An Approach for Quantifying and Correcting Sample Size-Related Bias in Population Estimates of Climate-Tree Growth Relationships. Forest Science, 59, 444-452. http://dx.doi.org/10.5849/forsci.12-047

Pretzsch, H., Biber, P., Schütze, G., Uhl, E., \& Rötzer, T. (2014). Forest Stand Growth Dynamics in Central Europe Have Accelerated since 1870. Nature Communications, 5, Article ID: 4967. http://dx.doi.org/10.1038/ncomms5967

Sedmák, R., \& Scheer, L. (2015). Properties and Prediction Accuracy of a Sigmoid Function of Time-Determinate Growth. iForest, e1-e7. http://www.sisef.it/iforest/contents/?id=ifor1243-007 